\title{
A Study on Factors Affecting Consumers Decision to Purchase Vegetables
}

\author{
Kanchan Singh and Neeraj* \\ Department of Agriculture and Environmental Sciences, National Institute of Food \\ Technology Entrepreneurship and Management, India
}

*Corresponding author

\begin{tabular}{|c|}
\hline Keywords \\
\hline $\begin{array}{l}\text { Consumer } \\
\text { behaviour, } \\
\text { Vegetable purchase, } \\
\text { Vegetable safety }\end{array}$ \\
\hline Article Info \\
\hline $\begin{array}{l}\text { Accepted: } \\
10 \text { January } 2018 \\
\text { Available Online: } \\
10 \text { February } 2018\end{array}$ \\
\hline
\end{tabular}

\section{Introduction}

Fresh vegetables are integral part of consumer's food expenditure. Every consumer wants good value for money in market for making purchase of fresh vegetable and also looks forward to have good quality, pest and disease free, hygienic and safe produce at affordable price. The lifestyle changes in recent times has made an impact on purchasing behaviour of consumers owing to rise in spendable income, rise in dual income groups, less time to spend in local mandi markets, accessibility to online purchase platforms, etc. (Akpinar et al., 2009). Consumers would also like to prefer healthy and good quality vegetables but yet the decision- making process is complex and the importance of motives (hygiene, pesticides residue, etc) and barriers (price, awareness, 
etc.) may affect the buying behaviour of consumers (Padel and Foster, 2005). Huang et al., (1999) and Liu et al., (2013) also describes about the affinity of consumers to have hazard free food which primarily is characterized by good quality, nutritious and free from harmful or toxic residues, such as fertilizers, pesticides, heavy metals, and nitrates are controlled within limits set by national standards.

The act of consumption influences consumers purchasing decisions and the decision to purchase is further influenced by price (Bagozzi and Dholakia, 1999). However, as far as fresh vegetables are concerned, nonprice factors like product quality, shelf like, place of purchase, place of origin of vegetable, nutrition values, awareness on safety concerns etc., play an important role in determining purchase decision (Chikkamath et al., 2012).

As consumers are integral part of vegetable supply chain and also act as end users, the present study was undertaken with an attempt to investigate the consumer behavior and concern during supply chain of fresh vegetables in Delhi region with a major objective to identify the factors influencing the purchasing decision of vegetables.

\section{Materials and Methods}

The current study has been undertaken in Delhi region to identify the consumer's preference while purchasing fresh vegetables. The primary data was collected with the help of questionnaire-based personal interview technique across Delhi region in order to understand their purchasing behavior. The structured questionnaire was divided in four major components viz., 1. Demographic characteristics of respondents (Table 1a), 2. Consumer's behavior on vegetable purchase (Table 1b), 3. Consumer's concerns on vegetable safety (Table 1c) and 4. Consumer's dependence on information channel (Table 1d). A 5-point Likert scale ranging from "very unconcerned" (1), "neutral" (3) to "very concerned" (5) was used to evaluate the degree of factors affecting vegetables purchase and consumer's concerns on vegetable safety. Responses of 137 consumers were collected. Data set were analyzed using Microsoft Excel and SPSS.

The data collected has been analyzed to understand respondent's demographic profiles, vegetables purchase place and frequency, kind of vegetable preference, knowledge on nutritional aspects of vegetables, vegetable safety, willingness to pay, methods to deal with problematic vegetables and sources of information.

\section{Results and Discussion}

\section{Respondent's demographic profile}

The Table 2 summarizes the demographics profile of the respondents by gender, age, educational background and Income level.

The results indicate that majority of respondents were male $(66 \%)$ followed by females. This probably is indicative that while going back to home from office, people prefer to purchase vegetables. This is also indicative of concerns that people prefer to buy fresh vegetables for cooking. About $57 \%$ of the respondent's fall in age bracket of 25-45 years.

Most of the respondents were at least graduate (38.69\%) followed by high school/intermediate $(32.85 \%)$. Most of the respondents were in category of < Rs. 5,000 (29.20\%) followed by > Rs. 25,000 (24.09\%). The overall profile suggests that the most of the respondents in this survey were young and middle age with high education and belonged to low income group. 


\section{Consumer's behavior on vegetable Understanding of nutritional importance of purchase vegetables}

Vegetable purchase frequency of Most of the respondents/consumers $(73 \%)$ respondents

were aware about the nutritional benefits of vegetables (Table 6). But still 27\% respondents were not very clear about the nutritional advantage of vegetables.

For the dataset under study, the purchase behavior of consumers for buying vegetables has been presented in Table 3 .

The results indicate that most the respondents $(34.31 \%)$ prefer buying vegetables more than once in a week followed by about $25.55 \%$ respondents who prefer to buy vegetables daily. About 18\% respondents procured vegetables once in a week.

\section{Preferred place for vegetables purchase}

The results showed that most of the consumers (71.53\%) prefer local market for buying vegetables (Table 4). In personal interview they also revealed that vegetables in supermarket are not fresh and vegetables sold in local markets are fresh and cheaper therefore most respondents chose local market to buy vegetables frequently.

Respondents find more diverse produce in local market and being close to their home or work place.

So it is suggested that actor in supply chain of vegetables should find a way to increase the consumers trust in vegetables sold at other places rather than local market. There were $19.71 \%$ respondents who trusted the supermarket.

Vegetable purchase preference in terms of fresh or packed

The results indicate that respondents/ consumers preferred to buy fresh vegetables (88.32\%) prefer to buy fresh vegetables as compared to packaged vegetables (Table 5).

\section{Factors influencing consumer purchase on vegetables}

The data related to the factors influencing consumers' purchase on vegetables is presented in Table 7. As per the results obtained freshness and price are two most important concerns affecting the purchase of fresh vegetables whereas the total quality i.e. external appearance and aroma ranked third in preference. The shelf life is defined as the period after the product becomes unacceptable for consumption from sensorial and nutritional or microbial safety perspectives. Shelf life was not a major concern for respondents. The other factors having lower level of concern include place of purchase, brand outlet and place of origin respectively.

The statistical analysis was performed to access the impact of vegetable purchase related factors to demographic concerns by using one way ANOVA (Analysis of Variance). The level of significance was set at 0.05 . A value of $\mathrm{P}<0.05$ was considered statistically significant and highlighted in bold (Table 8). The data presented in Table 8, also indicates that Gender has significant concern related to the importance of freshness and females are more concerned for freshness of the vegetable during purchase as compare to that of male counterparts. The age also has an impact freshness concern of vegetables and results indicate that respondents of middle age group (25-45 years) are more concerned for freshness than higher age respondents and younger age respondents. 
Table.1a Demographic characteristics of respondents

\begin{tabular}{l|l|l|l} 
Gender & Age group & Education level & Income level \\
\hline Male & $<25$ years & Illiterate, & $<$ Rs.5,000, \\
Female & 25-35 years & Below Junior High School, & Rs. 5,000-10,000, \\
& 36-45 years & High School/Intermediate, & Rs.10,000-20,000, \\
& $>45$ years & Graduate, & Rs. 20,000-25,000, \\
& & Post Graduate/Above & $>$ Rs. 25,000
\end{tabular}

Table.1b Questions asked in consumer's behavior on vegetable purchase

1. How frequently do you buy vegetables? (Daily, Once in a week, More than once in a week, Once in a month, More than once in a month, Seldom, Never)

2. Which place do you prefer to purchase vegetables? (Local market, Super market, Wholesale market, Online, Other)

3. Which kind of vegetable do you prefer to purchase?(Fresh, Packaged/Frozen)

4. Do you understand nutritional knowledge about vegetables?(Yes, No)

5. For each of the factor (Freshness, Shelf-life, Price, Brand outlet, Place of purchase, Place of origin, and Total quality) that affects consumer's buying decision were indicated for: 1) Very unconcerned; 2) Unconcerned; 3) Neutral; 4) Concerned or 5) Very concerned ?

Table.1c Questions asked in consumer's concerns on vegetable safety

1. Which stage of supply chain is the most risky to cause vegetable safety problem as perceived by consumers? (Production, Processing, Transportation, Sale, Consumption, Other)

2. For each of the safety factor (Pesticide residue, Excessive additives, Heavy metals, Microbial contamination, and Packaging contamination) that affects buying decision, please indicate whether you are: 1) very unconcerned; 2) Unconcerned; 3) Neutral; 4) Concerned or 5) Very concerned?

3. Do you satisfy with safety of vegetables? (Yes, No)

4. Are you willing to pay more for safe vegetables i.e. certified vegetables, if yes then how much more you are willing to pay?[yes $(0-10 \%, 10-20 \%,>20 \%)$, No]

5. By which method do you deal with problematic vegetables (i.e. spoilage, insects etc.) after purchase?(Returning, Complaining to relevant vendor, Discarding, Other)

Table.1d Consumer's dependence on information channel

\section{From which source do you get the food safety information?}

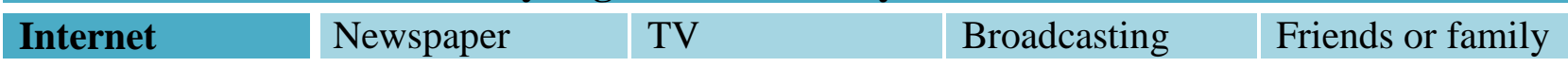


Table.2 Demographic profile of respondents

\begin{tabular}{|c|c|c|c|}
\hline $\begin{array}{l}\text { Demographic } \\
\text { characteristics }\end{array}$ & Category & Number & Percentage \\
\hline \multirow[t]{2}{*}{ Gender } & Male & 90 & 66 \\
\hline & Female & 47 & 34 \\
\hline \multirow[t]{4}{*}{ Age } & $<25$ years & 40 & 29.20 \\
\hline & $25-35$ years & 44 & 32.12 \\
\hline & $36-45$ years & 35 & 25.55 \\
\hline & $>45$ years & 18 & 13.14 \\
\hline \multirow[t]{5}{*}{ Education } & Illiterate & 6 & 4.38 \\
\hline & Below Junior High School & 17 & 12.41 \\
\hline & High School/Intermediate & 45 & 32.85 \\
\hline & Graduate & 53 & 38.69 \\
\hline & Post Gradate/Above & 16 & 11.68 \\
\hline \multirow{5}{*}{ Monthly Income } & $<$ Rs. 5,000 & 40 & 29.20 \\
\hline & Rs. $5,000-10,000$ & 21 & 15.33 \\
\hline & Rs. $10,000-20,000$ & 20 & 14.60 \\
\hline & Rs. $20,000-25,000$ & 23 & 16.79 \\
\hline & > Rs. 25,000 & 33 & 24.09 \\
\hline
\end{tabular}

Table.3 Vegetable purchase frequency

\begin{tabular}{|l|l|l|}
\hline Purchase frequency & Number & Percentage \\
\hline Daily & 35 & 25.55 \\
\hline Once in a week & 26 & 18.98 \\
\hline More than once in a week & 47 & 34.31 \\
\hline Once in a month & 8 & 5.84 \\
\hline More than once in a month & 15 & 10.95 \\
\hline Seldom & 5 & 3.65 \\
\hline Never & 1 & 0.73 \\
\hline
\end{tabular}

Table.4 Preferred location for vegetable purchase

\begin{tabular}{|l|}
\hline Purchase location \\
\hline Local market \\
\hline Super market \\
\hline Wholesale market \\
\hline Online \\
\hline Other
\end{tabular}

\begin{tabular}{|l|l|}
\hline Number & Percentage \\
\hline 98 & 71.53 \\
\hline 27 & 19.71 \\
\hline 18 & 13.14 \\
\hline 2 & 1.46 \\
\hline 5 & 3.65 \\
\hline
\end{tabular}


Table.5 Vegetable preference of respondents (fresh vs packed)

\begin{tabular}{|l|l|l|}
\hline Preference & Number & Percentage \\
\hline Fresh & 121 & 88.32 \\
\hline Packaged & 16 & 11.67 \\
\hline
\end{tabular}

Table.6 Respondent's nutritional knowledge about vegetables

\begin{tabular}{|l|c|c|}
\hline Respondents & Number & Percentage \\
\hline Yes & 100 & 72.99 \\
\hline No & 37 & 27.01 \\
\hline
\end{tabular}

Table.7 Rank of the factors influencing consumer purchase on vegetables

\begin{tabular}{|l|c|c|}
\hline Factors & Mean & \pm SD \\
\hline Freshness & 4.4306 & 0.7933 \\
\hline Price & 3.9781 & 1.0535 \\
\hline Total quality & 3.8467 & 1.0138 \\
\hline Shelf life & 3.7664 & 1.1065 \\
\hline Place of purchase & 3.3869 & 1.0931 \\
\hline Brand outlet & 2.5620 & 1.0769 \\
\hline Place of origin & 2.3942 & 1.2681 \\
\hline
\end{tabular}

Table.8 The differences of the consumers' concerns on the factors influencing consumers' purchases on vegetables with different demographic groups

\begin{tabular}{|l|l|c|c|c|c|}
\hline S. No. & \multicolumn{1}{|c|}{ Factor } & Gender & Age & $\begin{array}{c}\text { Education } \\
\text { Level }\end{array}$ & $\begin{array}{c}\text { Income } \\
\text { Level }\end{array}$ \\
\hline & & P value & P value & P value & P value \\
\hline $\mathbf{1 .}$ & Freshness & $\mathbf{. 0 2 6}$ & .448 & .612 & $\mathbf{. 0 0 1}$ \\
\hline $\mathbf{2 .}$ & Shelf life & .051 & $\mathbf{. 0 0 1}$ & .525 & $\mathbf{. 0 0 1}$ \\
\hline $\mathbf{3 .}$ & Price & $\mathbf{. 0 3 9}$ & $\mathbf{. 0 1 7}$ & $\mathbf{. 0 2 5}$ & .097 \\
\hline $\mathbf{4 .}$ & Brand outlet & .688 & .075 & $\mathbf{. 0 2 1}$ & $\mathbf{. 0 0 1}$ \\
\hline $\mathbf{5 .}$ & Place of purchase & .766 & .315 & .061 & .224 \\
\hline $\mathbf{6 .}$ & Place of origin & .360 & .297 & .117 & $\mathbf{. 0 1 6}$ \\
\hline $\mathbf{7 .}$ & Total quality & $\mathbf{. 0 1 9}$ & .069 & .699 & $\mathbf{. 0 4 0}$ \\
\hline
\end{tabular}


Table.9 Consumers responses towards factors influencing consumer purchase on vegetables

\begin{tabular}{|c|c|c|c|c|c|c|c|c|c|c|c|c|}
\hline \multirow{2}{*}{$\begin{array}{l}\text { Respon } \\
\text { dent's } \\
\text { concer } \\
\text { n's }\end{array}$} & \multicolumn{2}{|c|}{ Price } & \multicolumn{2}{|c|}{ Total quality } & \multicolumn{2}{|c|}{ Shelf life } & \multicolumn{2}{|c|}{$\begin{array}{l}\text { Place of } \\
\text { purchase }\end{array}$} & \multicolumn{2}{|c|}{ Brand outlet } & \multicolumn{2}{|c|}{$\begin{array}{l}\text { Place of } \\
\text { origin of } \\
\text { vegetable }\end{array}$} \\
\hline & $\begin{array}{l}\text { Frequ } \\
\text { ency }\end{array}$ & $\begin{array}{l}\text { Per } \\
\text { cent }\end{array}$ & $\begin{array}{c}\text { Frequ } \\
\text { ency }\end{array}$ & $\begin{array}{l}\text { Per } \\
\text { cent }\end{array}$ & $\begin{array}{l}\text { Frequ } \\
\text { ency }\end{array}$ & $\begin{array}{l}\text { Per } \\
\text { cent }\end{array}$ & $\begin{array}{l}\text { Frequ } \\
\text { ency }\end{array}$ & $\begin{array}{l}\text { Per } \\
\text { cent }\end{array}$ & $\begin{array}{l}\text { Frequ } \\
\text { ency }\end{array}$ & $\begin{array}{l}\text { Per } \\
\text { cent }\end{array}$ & $\begin{array}{l}\text { Frequ } \\
\text { ency }\end{array}$ & $\begin{array}{l}\text { Per } \\
\text { cent }\end{array}$ \\
\hline $\begin{array}{l}\text { Very } \\
\text { Unconc } \\
\text { erned }\end{array}$ & 5.00 & 3.60 & 4.00 & 2.90 & 3.00 & 2.20 & 11.00 & 8.00 & 26.00 & $\begin{array}{c}19.0 \\
0\end{array}$ & 44.00 & $\begin{array}{c}32.1 \\
0\end{array}$ \\
\hline $\begin{array}{l}\text { Unconc } \\
\text { erned }\end{array}$ & 8.00 & 5.80 & 13.00 & 9.50 & 24.00 & $\begin{array}{c}17.5 \\
0\end{array}$ & 13.00 & 9.50 & 39.00 & $\begin{array}{c}28.5 \\
0\end{array}$ & 35.00 & $\begin{array}{c}25.5 \\
0\end{array}$ \\
\hline Neutral & 23.00 & $\begin{array}{c}16.8 \\
0\end{array}$ & 19.00 & $\begin{array}{c}13.9 \\
0\end{array}$ & 13.00 & 9.50 & 44.00 & $\begin{array}{c}32.1 \\
0\end{array}$ & 46.00 & $\begin{array}{c}33.6 \\
0\end{array}$ & 27.00 & $\begin{array}{c}19.7 \\
0\end{array}$ \\
\hline $\begin{array}{l}\text { Concer } \\
\text { ned }\end{array}$ & 50.00 & $\begin{array}{c}36.5 \\
0\end{array}$ & 65.00 & $\begin{array}{c}47.4 \\
0\end{array}$ & 59.00 & $\begin{array}{c}43.1 \\
0\end{array}$ & 50.00 & $\begin{array}{c}36.5 \\
0\end{array}$ & 21.00 & $\begin{array}{c}15.3 \\
0\end{array}$ & 22.00 & $\begin{array}{c}16.1 \\
0\end{array}$ \\
\hline $\begin{array}{l}\text { Very } \\
\text { Concer } \\
\text { ned }\end{array}$ & 51.00 & $\begin{array}{c}37.2 \\
0\end{array}$ & 36.00 & $\begin{array}{c}26.3 \\
0\end{array}$ & 38.00 & $\begin{array}{c}27.7 \\
0\end{array}$ & 19.00 & $\begin{array}{c}13.9 \\
0\end{array}$ & 5.00 & 3.60 & 9.00 & 6.60 \\
\hline Total & 137 & 100 & 137 & 100 & 137 & 100 & 137 & 100 & 137 & 100 & 137 & 100 \\
\hline
\end{tabular}

The figures in bold indicate the maximum common concern of respondents in specific group.

Table.10 The most risky stage consumers perceived through the vegetable supply chain

\begin{tabular}{|l|}
\hline Stage \\
\hline Production \\
\hline Processing \\
\hline Transportation \\
\hline Sale \\
\hline Consumption \\
\hline
\end{tabular}

\begin{tabular}{|c|c|}
\hline Number & Percentage \\
\hline 57 & 41.61 \\
\hline 34 & 24.82 \\
\hline 40 & 29.20 \\
\hline 21 & 15.33 \\
\hline 4 & 2.92 \\
\hline
\end{tabular}

Table.11 Frequency of various responses regarding factors on vegetable safety

\begin{tabular}{|c|c|c|c|c|c|c|c|c|c|c|}
\hline \multirow[t]{2}{*}{$\begin{array}{l}\text { Respondent's } \\
\text { concern's }\end{array}$} & \multicolumn{2}{|c|}{$\begin{array}{c}\text { Pesticide } \\
\text { residues }\end{array}$} & \multicolumn{2}{|c|}{$\begin{array}{l}\text { Excessive } \\
\text { additives }\end{array}$} & \multicolumn{2}{|c|}{ Heavy metals } & \multicolumn{2}{|c|}{$\begin{array}{l}\text { Packaging } \\
\text { contamination }\end{array}$} & \multicolumn{2}{|c|}{$\begin{array}{c}\text { Microbial } \\
\text { contamination }\end{array}$} \\
\hline & $\begin{array}{l}\text { Frequ } \\
\text { ency }\end{array}$ & $\begin{array}{c}\text { Perce } \\
\text { nt }\end{array}$ & $\begin{array}{l}\text { Frequ } \\
\text { ency }\end{array}$ & $\begin{array}{c}\text { Perce } \\
\text { nt }\end{array}$ & $\begin{array}{c}\text { Freque } \\
\text { ncy }\end{array}$ & $\begin{array}{c}\text { Perce } \\
\text { nt }\end{array}$ & $\begin{array}{l}\text { Freque } \\
\text { ncy }\end{array}$ & $\begin{array}{c}\text { Perce } \\
\text { nt }\end{array}$ & $\begin{array}{l}\text { Freque } \\
\text { ncy }\end{array}$ & $\begin{array}{c}\text { Perc } \\
\text { ent }\end{array}$ \\
\hline $\begin{array}{l}\text { Very } \\
\text { Unconcerned }\end{array}$ & 6.00 & 4.40 & 5.00 & 3.60 & 7.00 & 5.10 & 0.00 & 0.00 & 4.00 & 2.90 \\
\hline Unconcerned & 6.00 & 4.40 & 15.00 & 10.90 & 15.00 & 10.90 & 12.00 & 8.80 & 12.00 & 8.80 \\
\hline Neutral & 20.00 & 14.60 & 36.00 & 26.30 & 35.00 & 25.50 & 41.00 & 29.90 & 27.00 & 19.70 \\
\hline Concerned & 55.00 & 40.10 & 60.00 & 43.80 & 52.00 & 38.00 & 62.00 & 45.30 & 46.00 & 33.60 \\
\hline $\begin{array}{l}\text { Very } \\
\text { Concerned }\end{array}$ & 50.00 & 36.50 & 21.00 & 15.30 & 28.00 & 20.40 & 22.00 & 16.10 & 48.00 & 35.00 \\
\hline Total & 137 & 100 & 137 & 100 & 137 & 100 & 137 & 100 & 137 & 100 \\
\hline
\end{tabular}

The figures in bold indicate the maximum common concern of respondents in specific group. 
Table.12a Consumers trust on vegetables safety

\begin{tabular}{|l|c|c|}
\hline Trust on vegetable's safety & Number & Percentage \\
\hline No & 98 & 71.53 \\
\hline Yes & 39 & 28.47 \\
\hline
\end{tabular}

Table.12b Willingness to pay (WTP) for safe and quality vegetables

\begin{tabular}{|l|l|c|c|}
\hline WTP & & Number & Percentage \\
\hline No & & 59 & 43.07 \\
\hline Yes & $0-10 \%$ & $\mathbf{7 8}$ & $\mathbf{5 6 . 9 3}$ \\
\hline If Yes, then to what \\
extent in terms of & $10-20 \%$ & 43 & 31.39 \\
\hline extra/higher price & $>20 \%$ & 32 & 23.36 \\
\hline
\end{tabular}

Table.13 Method preference to deal with problematic vegetables

\begin{tabular}{|l|c|c|}
\hline Method & Number & Percentage \\
\hline Returning & 45 & 32.85 \\
\hline Complaining with vendor & 54 & 39.42 \\
\hline Discarding & 47 & 34.31 \\
\hline Other & 4 & 2.92 \\
\hline
\end{tabular}

Table.14 Consumer's dependency on information channel

\begin{tabular}{|l|c|c|}
\hline Channel & Number & Percentage \\
\hline Friends and family & 52 & 37.96 \\
\hline TV & 40 & 29.20 \\
\hline Internet & 35 & 25.55 \\
\hline Newspaper & 28 & 20.44 \\
\hline Broadcasting (Radio) & 9 & 6.57 \\
\hline Others & 7 & 5.11 \\
\hline
\end{tabular}

The results also shows that gender is not significantly related to shelf life, brand outlet, place of purchase and place of origin. Age is not significantly related with brand outlet, place of purchase, place of origin, freshness and total quality. Education is not significantly related with freshness, price, place of purchase, place of origin and total quality. In a similar kind of study Cheng et $a l ., 2016$ identified seven factors as freshness, shelf life, total quality, place of purchase, price, place of origin and brand were identified as the factors influencing consumers' vegetable purchase. His study also indicated that freshness and shelf life as top two concerns for vegetable purchase and brand ranked as the least concern in this study when consumers made their purchase decisions on vegetables. Freshness is a decisive attribute for consumers to choose vegetables. Consumer's perception of freshness is likely to involved many aspects 
as shelf life, nutritional value, safety and sensory aspects (Peneau et al., 2009). Therefore, consumers want to take freshness as their top consideration when they purchase vegetables.

The results related to consumer's responses towards various factors influencing their decision to purchase vegetables are presented in the Table 9. The results indicate that majority of respondents i.e. $73.7 \%$ (37.20\%: very concerned and $36.50 \%$ Concerned) are concerned about the price they are paying for buying the vegetables. About $47.40 \%$ and $43.10 \%$ respondents are concerned about the total quality and shelf life of vegetable being purchased by them. About $50 \%$ of the respondents $(36.50 \%$ concerned and $13.90 \%$ very concerned) were concerned about the place from where they are purchasing the vegetables whereas remaining were either neutral or not very concerned about this aspect. About $81 \%$ of the respondents (19.00\% Very unconcerned, $28.50 \%$ Unconcerned and $33.60 \%$ Neutral) were not very cautious and concerned about the name of brand outlet for purchase of vegetables. It was also interesting to note that about $57 \%$ of vegetable purchasing respondents $(32.10 \%$ Very unconcerned, $25.50 \%$ Unconcerned) were not at all having concerns related to the place of the origin of the vegetables.

\section{Consumer concerns on vegetable safety}

\section{Most risky stage consumers perceived through the vegetable supply chain}

Table 10 shows perceptions of different respondent's on the most risky stage through vegetable supply chain. Most of the respondents $(41.61 \%)$ believed that the agriculture production stage was one of the most risky stage to cause vegetable safety problems indicating a big concern on what happened to the vegetables on the farm level.
The safety hazards in vegetables such as pesticide residues and heavy metal contamination may have direct impact on quality of vegetable at farm gate level. $29.20 \%$ respondents perceived the vegetable transportation stage was a crucial stage where safety of vegetables is most likely to be compromised. There were only $15.33 \%$ and $2.92 \%$ people perceived sale and consumption stage as the ones with the highest risk, respectively.

The results find support from the study of Danelon and Salay (2012) which highlights that vegetables can be contaminated during the agriculture production, transportation, storage, preparation, distribution and consumption stages. The demand by urban consumers for blemish-free and attractive produce encourages excessive use of pesticides and nitrate-rich chemical fertilizers.

\section{Consumer concerns on vegetable safety related to contamination}

Data presented in the Table 11, shows that about $76.60 \%$ (40.1\% concerned and $36.5 \%$ very concerned) respondents were concerned about pesticide residues present in vegetables. About $43.80 \%$ of respondents were concerned while only $15.35 \%$ of respondents were very much concerned about excessive additives present in vegetables and $26.30 \%$ were neutral about presence of excessive additives in purchased vegetable. This shows lack of knowledge among consumers about safety factors. Excessive additive here refers to use of chemicals and insecticides for bleaching and cleaning of vegetables for improving the appearance, color enhancers, coatings, glossy sprays, etc. Regarding heavy metal contamination, about $58 \%$ respondents were concerned $(35.60 \%$ Highly concerned and $33.60 \%$ Concerned) about heavy metals present in purchased vegetables and a total of $41.6 \%$ were neutral, unconcerned or very 
unconcerned about this aspect. About $61 \%$ respondents are concerned about the packaging and contamination due to poor packaging of the vegetables whereas a large group of respondents (about 30\%) is neutral on this aspect which may be due to their lack of awareness about the bulk packaging and handling of vegetable produce. Regarding the microbial safety of the vegetables, $68.60 \%$ respondents were concerned out of which $35.0 \%$ are highly concerned while $33.60 \%$ of respondents were concerned about microbial contamination of purchased vegetables. Access to clean water for irrigating vegetables represents a major challenge. Sewage water contains a broad spectrum of pathogens, which survives for several weeks in the field (Carl Johan Lagerkvist et al., 2013).

Previous studies have also reported and observed that some crops including vegetables were contaminated with heavy metals in some polluted areas in China (Fu et al., 2008) and several food scares of heavy metal contamination on vegetables in China and India (Huang et al., 2014).

All these hazard risks are increasingly becoming a concern for fresh vegetable consumption. Hence, it is important for the fresh vegetable suppliers to assure the safety of fresh vegetables and establish or maintain consumer's trust in fresh vegetables by providing safe vegetables as a kind of healthy food (Cheng et al., 2016).

Consumer studies on purchase behavior and safety concern need to be carried out to help the food industry to control product safety and quality. Many studies have also measured the perceptions of consumers on different aspects of food safety (Shim et al., 2011; Van Boxstael et al., 2014). A limited number of studies are focused on consumer's perception of vegetable safety risks, such as pesticide residues and product freshness.
Consumers' trust on vegetable safety and willingness to pay

Data presented in Table 12a indicates that only $28.47 \%$ respondents believe that vegetables which they are purchasing for consumption are safe while majority of respondents $(71.53 \%)$ believe that vegetables they are purchasing from the market are not safe for consumption. The results presented in the Table $12 \mathrm{~b}$ also indicate that, out of all the consumers interviewed $56.93 \%$ respondents were willing to pay higher price for safe and certified vegetables out of which $31.39 \%$ respondents were willing to pay $0-10 \%$ higher price followed by $23.36 \%$ of respondents who were ready to pay upto $10-20 \%$ higher price for safe and quality vegetables.

This also indicates that if consumer is made aware and educated on aspects of safe, certified and quality vegetable produce in markets, this may develop as a niche area for health and quality conscious consumers.

\section{Method to deal with poor quality vegetables}

The respondents were asked about how they deal with a situation when vendor dodges them by giving poor quality of vegetables while making a purchase, most of the respondents $(39.42 \%)$ claimed that they complained to the vendors. About $34 \%$ would like to discard and will not use whereas and $32.85 \%$ respondents said that they return the problematic vegetables to the vendors (Table 13). Consumers may select points of purchase through beliefs in risk reduction and trust, but may not reap all of the benefits of selecting these purchase locations. Similarly, lack of information and distrust between producers and consumers has been found to adversely affect the introduction of changes to the food delivery system in developing countries (Mergenthaler et al., 2009). 


\section{Consumer's dependence on information channel}

Out of various channels, the information received by the consumers/ respondents regarding vegetable quality, food safety concerns falls at large in the trusted group of friends and family (Table 14). About $92.71 \%$ respondents receive information from three broad channels viz., Friends and family (37.96\%), TV (29.20\%) and Internet (25.55\%). In a study conducted on Chinese consumers, it was also revealed that consumers mainly obtain information about safe food from television and newspapers, prior experience, relatives and friends. Magazines, professional books and the internet are less frequently used (Liu et al., 2013). While consumers are exposed to more information than ever before, it is important to understand that more information does not necessarily mean better informed consumers. Verbeke (2005) stressed that information should be properly managed and targeted to address particular needs as not all consumers are alike. Interested consumers could be engaged to purposefully seek information. Risk perception also depends on the information sources that consumer's use, which can include the mass media, friends and personal experience (Cheng et al., 2016). The study was an attempt to understand the concerns of consumers in Delhi regarding purchase of vegetables which included concerns like vegetables purchase place and frequency, kind of vegetable preference, knowledge on nutritional aspects of vegetables, vegetable safety, willingness to pay, methods to deal with problematic vegetables and sources of information, etc. The results shows that gender, education, age have impact on buying behaviour and purchase decision of consumers regarding vegetables. Gender showed significant concern related to the importance of freshness as females buyers were more concerned about freshness of the vegetable during purchase in comparison to male counterparts. Most of the respondents preferred buying vegetables more than once in a week followed by respondents who prefer to buy vegetables daily. There was keen concern of respondents to buy fresh vegetables rather than packaged ones. They also had higher preference for purchasing vegetables from local market rather than super markets. Most of the respondents were aware about the nutritional benefits of vegetables. Freshness and price were two most important concerns that affected the purchase of fresh vegetables whereas the total quality i.e. external appearance and aroma ranked third in preference. The other factors having lower level of concern include place of purchase, brand outlet and place of origin, respectively. The results also indicate that consumers have concerns about the price of vegetable being paid by them for the purchase of vegetables. They considered the production stage at farm as one of the most risky stage in supply chain of vegetables. Respondents also had higher perception that the vegetables they are purchasing are not very safe and if an opportunity given, they would like to buy safe and certified vegetables even at little higher price. Most of the respondents received information from three broad channels viz., friends and family, TV and internet.

\section{References}

Akpinar, M.G., Aykin, S.M., Sayin, C. and Ozkan, B. 2009. The role of demographic variables in purchasing decisions on fresh fruit and vegetables. Journal of Food, Agriculture and Environment. 7 (3/4): 106-110.

Bagozzi, R.P. and Dholakia, U. 1999. Goal setting and goal striving in consumer behavior. The Journal of Marketing. 1932.

Cheng, L., Jiang, S., Zhang, S., You, H., Zhang, J., Zhou, Z., Xiao, Y., Liu, X., 
Du, Y., Li, J. and Wang, X. 2016. Consumers' behaviors and concerns on fresh vegetable purchase and safety in Beijing urban areas, China. Food Control. 63: 101-109.

Chikkamath, M., Atteri, B.R., Srivastava, S.K. and Roy, S. 2012. Factors influencing consumer's behaviour for vegetable purchase. Vegetable Science. 39 (1): 35-39.

Danelon, M.S. and Salay, E. 2012. Perceived physical risk and risk-reducing strategies in the consumption of raw vegetable salads in restaurants. Food Control. 28 (2): 412-419.

Fu, J., Zhou, Q., Liu, J., Liu, W., Wang, T., Zhang, Q. and Jiang, G. 2008. High levels of heavy metals in rice Oryzasativa L. from a typical E-waste recycling area in southeast China and its potential risk to human health. Chemosphere. 71 (7): 1269-1275.

Huang G.F., Wu Q.T., Rong T.Y., You Z.L., Jiang C.A. 1999. Environmental quality assessment of hazard free vegetable production area. Research of Environmental Science. 12 (4): 54-56.

Huang, Z., Pan, X.D., Wu, P.G., Han, J.L. and Chen, Q. 2014. Heavy metals in vegetables and the health risk to population in Zhejiang, China. Food Control. 36(1): 248-252.

Lagerkvist, C.J., Hess, S., Okello, J., Hansson, H. and Karanja, N. 2013. Food health risk perceptions among consumers, farmers, and traders of leafy vegetables in Nairobi. Food Policy. 38: 92-104.
Liu, R., Pieniak, Z. and Verbeke, W. 2013. Consumers' attitudes and behaviour towards safe food in China: A review. Food Control. 33 (1): 93-104.

Mergenthaler, M., Weinberger, K. and Qaim, M. 2009. The food system transformation in developing countries: A disaggregate demand analysis for fruits and vegetables in Vietnam. Food Policy. 34 (5): 426-436.

Padel, S. and Foster, C. 2005. Exploring the gap between attitudes and behaviour: Understanding why consumers buy or do not buy organic food. British Food Journal. 107 (8): 606-625.

Peneau, S., Linke, A., Escher, F. and Nuessli, J. 2009. Freshness of fruits and vegetables: consumer language and perception. British Food Journal. 111 (3): 243-256.

Shim, S.M., Seo, S.H., Lee, Y., Moon, G.I., Kim, M.S. and Park, J.H. 2011. Consumers' knowledge and safety perceptions of food additives: Evaluation on the effectiveness of transmitting information on preservatives. Food Control. 22(7): 1054-1060.

Van Boxstael, S., Devlieghere, F., Berkvens, D., Vermeulen, A. and Uyttendaele, M. 2014. Understanding and attitude regarding the shelf life labels and dates on pre-packed food products by Belgian consumers. Food Control. 37: 85-92.

Verbeke, W. 2005. Agriculture and the food industry in the information age. European review of agricultural economics. 32 (3): 347-368.

\section{How to cite this article:}

Kanchan Singh and Neeraj. 2018. A Study on Factors Affecting Consumers Decision to Purchase Vegetables. Int.J.Curr.Microbiol.App.Sci. 7(02): 1211-1222. doi: https://doi.org/10.20546/ijcmas.2018.702.149 